\title{
Utelatelsen av religiøse og spirituelle faktorer i vurdering av selvmordsrisiko
}

Ved Kim Larsen

\section{Jeg vil i det følgende argumentere for at man i vurdering av selvmordsrisiko tar for lite hen- syn til religiøse og spirituelle faktorer. Artikkelen tar ikke mål av seg til å være en utfyllende fremstilling av feltet, men er mer et vitenskapelig begrunnet debattinnlegg for hvorfor man i større grad bør inkorporere religiøse og spirituelle faktorer i vurdering av selvmordsrisiko. jeg vil i hovedsak omtale vestlige religioner.}

\section{ABSTRACT}

Religion og spiritualitet er vesentlige faktorer i menneskelivet. Empirisk forskning har konsekvent vist at religion har en helsefremmende effekt på både fysisk og psykisk helse. Forskning på religion og suicidalitet, både på populasjons- og individnivå, indikerer at religion er en beskyttende faktor for selvmord. Til tross for dette er religion konsekvent undervurdert i både psykiatri, psykologi og suicidologi. Noen av grunnene til dette drøftes. Det konkluderes med at religiøse og spirituelle faktorer bør inkluderes i kliniske vurderinger av selvmordsrisiko i større grad slik at vi betrakter pasienten innenfor en utvidet ramme som omfatter både biologi, psykologi, det sosiale og det spirituelle - slik at våre vurderinger av selvmordsrisiko blir mer komplette.

Religion and spirituality are basic ingredients in human life. Empirical research has repeatedly shown that religion has a salutogenic effect on both physical and psychological health. Research on religion and suicidality, both on population and individual levels, has indicated religion as a protective factor for suicide. In spite of this, religion is consistently overlooked in psychiatry, psychology and suicidology. Some explanations for this state of affairs are sought. It is concluded that religious and spiritual factors must be included in clinical evaluations of suicide risk to a higher extent for our conception of the patient as a biological, psychological, social and spiritual being to be complete and for our evaluations of suicide risk to be more comprehensive.

LEVERT: 24/09-12 REVIDERT: 23/01-13 AKSEPTERT: 08/03-13
Mennesket kan ikke leve uten mening (Frankl, 1959). Vi har et universelt behov for å gi mening og orden til universet og kreftene i kosmos, så vel som til dagligdagse hendelser (Berger, 1967; Berger \&t Kellner, 1982). Hvilken mening vi gir et fenomen vil være helt avgjørende for hvordan vi opplever det. Det er derfor Nietszches observasjon om at den som har et hvorfor ("Warum") kan tåle nesten ethvert hvordan ("Wie") oppleves som så treffende. Denne funksjonen som "meningsprodusent" i menneskelivet har i størstedelen av menneskets historie blitt ivaretatt av religionen (Berger, 1967; Geertz, 1966; Jarvis \& Northcott, 1987; Pargament, 1992; Spilka et. al., 1985). I menneskehetens historie har også meningstilskrivelsen til universet og kosmos ("der oppe") gått i ett med meningstilskrivelsen til samfunnet ("her nede"). Denne koblingen kan lett skape et totaliserende meningssystem som legitimerer forskjeller i et hierarkisk organisert samfunn med lav frihet, men med høy trygghet (Berger, 1967). Middelalderen er vel det klareste eksempelet på dette. I renessansen slår menneskets religiøse verdensbilde sprekker og blir i økende grad utfordret av vitenskapelige forklaringsmodeller og meningssystemer. Dette skaper et samfunn med større frihet og pluralisme, men bringer også med seg utrygghet og angst (Berger, 1980; Berger et. al., 1974; May, 1950). Menneskets behov for mening og orden blir i økende grad overtatt av vitenskapelige eller pseudovitenskapelige meningssystemer. Ernest Becker har i sin prisvinnende bok The denial of death (1973) gitt en analyse av hvordan han tenker seg at menneskelige handlinger kan forklares som forsøk på å transcendere døden (leve videre gjennom sine barn, bli en "god samfunnsborger" og oppfylle historisk tilfeldige sosiokulturelle krav, forsøke å bidra til kunsten eller vitenskapen, eller til og med gjennom ødeleggelser og herostratisk destruktivitet). En kan godt si at Becker gjør det samme for døden som Freud gjorde for seksualiteten; Becker benytter døden som en underliggende kausalfaktor som kan forklare et bredt spekter av menneskelige handlinger. Mens seksualitet har utviklet seg fra å være et tabu på Freuds tid til å bli overeksponert i vår tid, kan det argumenteres for at det i dag er døden som utgjør det ultimate tabu. Som Philippe Ariès har vist i sin monumentale mentalitetshistoriske studie The hour of our death (1983), har døden ikke i noen historisk epoke blitt opplevet som så truende som nå, samtidig som den er fjernet fra dagliglivet og flyttet inn i medisinske og profesjonelle institusjoner, usynlig og medikalisert.

\section{Religiøse og vitenskapelige for-} klaringer som vesensforskjellige

Det er flere viktige forskjeller på religiøse og vitenskapelige meningssystemer (Berger, 1980; Berger \& Kellner, 1982; Berger et. al., 1974). Vitenskapen gir årsaksforklaringer av teknisk og mekanistisk art, men disse er ikke så dypt meningsfylte og derved heller ikke så "trøstende" som religiøse forklaringer. Ta for eksempel den hendelsen som kanskje fremstår som det mest forferdelige og meningsløse som kan skje: et barns død. Religionen forsikrer oss om at "... ikke [en spurv] faller til jorden uten at deres Far er der", etc. Vi forsikres om at hendelsen har en mening, og selv om vi ikke oppfatter den nå, vil det komme en tid (etter døden) hvor vi skal komme til å forstå den. Vitenskapelige forklaringer av den samme hendelsen vil være essensielt annerledes, mer mekanistiske, mindre meningsbærende og derved mindre trøstende (Berger, 1980; Berger \& Kellner, 1982; Berger el. al., 1974). Vitenskapens forklaringsmodeller er essensielt annerledes og besvarer ikke spørsmålet om den dypeste mening. 


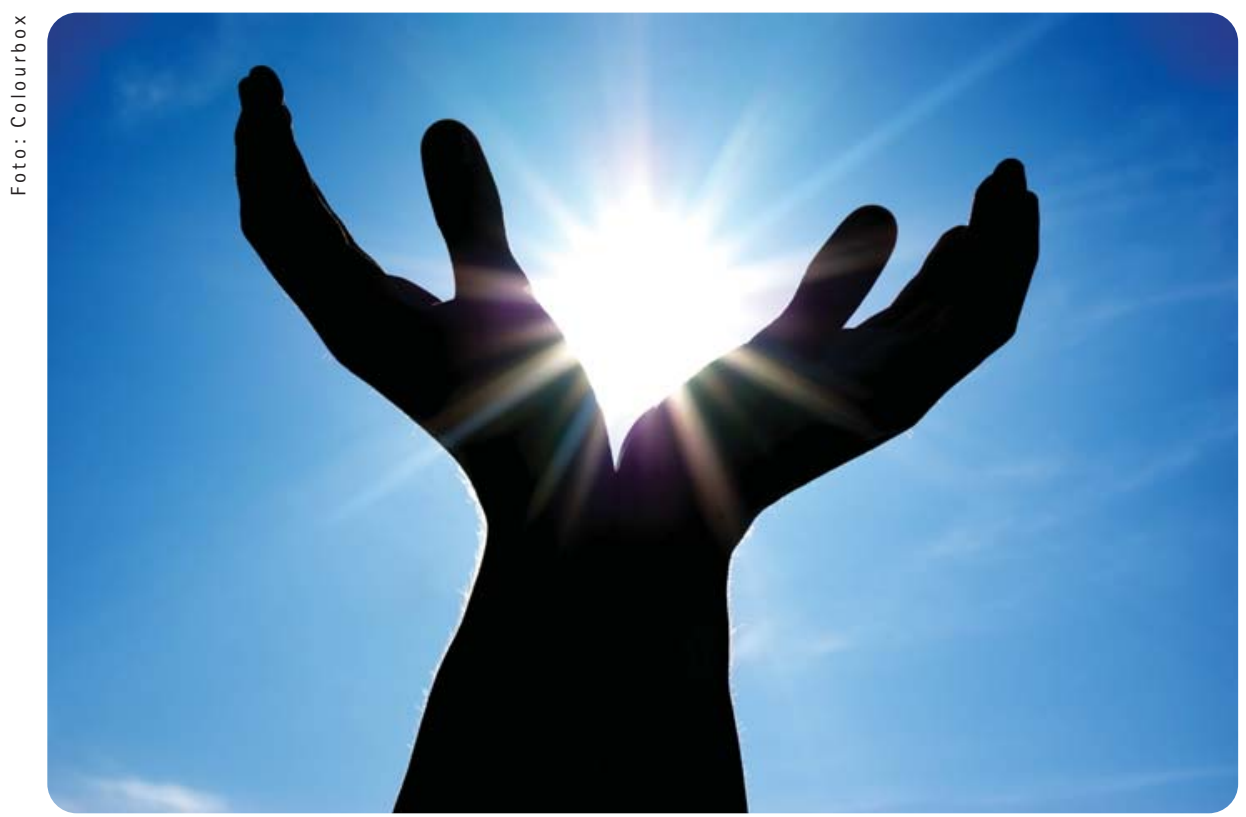

Ytterligere en forskjell er at en ikke kan utlede verdier og moral fra vitenskapen på samme måte som en kan det fra religionen (Berger \& Kellner, 1982; WeisskopfJoelsen, 1980). Dette forhindrer ikke at dette gjøres i rikt monn ved at en i dagens sekulariserte samfunn bruker vitenskapen som en pseudoreligion, noe tabloidpressens massive bombardement av såkalt helseinformasjon illustrerer. På samme måte som frelse var den ultimate verdi $i$ et religiøst meningssystem og tjente som begrunnelse for menneskelige handlinger, benyttes helse nå på samme måte (Szasz, 1970), og man utleder hvordan man skal leve sitt liv fra vitenskapen, som i utgangspunktet er verdifri. Vitenskapen beskriver kausalsammenhenger, ikke verdier eller mål.

\section{Religion og helse}

Sammenhengen mellom religion og helse er selvsagt komplekse, og en kan tenke seg flere modeller og virkningsmekanismer her (Koenig et. al., 1997; Pargament, 1990). Grovt sett ser en for seg at religion påvirker både fysisk og psykisk helse på tre måter.

1. Via adferd. Religiøse personer oppviser gjennomgående mer helsefremmende adferd (trim, turer i skog og mark) samt har et markant lavere inntak av rusmidler.
2. Via sosial støtte. Mange religiøse personer har tilknytning til kirkesamfunn og et støttende og ivaretagende miljø. Stressforskningen og helsepsykologien viser unisont at sosial støtte har en dempende effekt på stress og sykdom. (Cohen $\&$ Syme, 1985; Pilisuk \&t Parks, 1986).

3. Via mening. Religiøse personer får lettere et sterkt "sense of coherence" (Antonovsky, 1979) ved at religionen utgjør et meningssystem som kan anvendes $i$ en helsebringende fortolkning av livsbegivenheter og sykdom.

Man har funnet en sammenheng mellom religion og fysisk helse (se for eksempel Koenig, 1997; Koenig et. al., 2012; Larson et. al. 1997; Levin, 1994 for oversikter). Jarvis \& Northcott (1987) konkluderer slik i sin studie om religion og mortalitet: "...uansett hva som er ens eget teologiske ståsted, er det i økende grad blitt klart at religionen har en vesentlig innflytelse på måten mange mennesker lever, deres livskvalitet, og på hvor lang tid de lever og kan oppleve denne livskvaliteten."

(s. 822. Min oversettelse). Religiøsitet kan også være gunstig for rehabiliteringsprosessen etter en sykdom, slik for eksempel O'Brien (1982) har vist i sin studie av pasienter i vedvarende hemodialysebehandling. De pasientene som gav uttrykk for den mest positive oppfatningen av den betydning religionen hadde for deres aksept av sykdommen, hadde også den mest konstruktive tilpasningen til behandlingen; høyest egenaktivitet, høyest compliance med behandlingen og lavest fremmedgjøring ("alienation").

\section{Religion og psykisk helse}

Hva så med psykisk helse? En regner her med at sammenhengen er sterkere (George et. al., 2000). Larson et. al. (1992) undersøkte alle empiriske artikler som hadde inkludert et mål på religiøs tilknytning i to ledende amerikanske fagtidsskrifter i perioden 1978-1989. I det store flertall av studiene fantes det en positiv sammenheng mellom religiøsitet og psykisk helse. Et interessant funn var også at dette var sammenhenger som fremkom av empirien, men som i liten grad ble formulert som hypoteser på forhånd og som ofte heller ikke ble rapportert i artiklene. Larson et. al. (1992) fant at for kun 30 (22\%) av de 139 målene var det spesifisert en hypotese på forhånd. Av disse 30 ble resultatene kun rapportert i 12 tilfeller (40\%). De fant også at kun for 50 (36\%) av målene på religiøsitet, ble sammenhengen som ble funnet mellom religion og psykisk helse rapportert i studien. Siden depresjon er den psykiske lidelsen med sterkest tilknytning til selvmord, la oss se på noen studier som undersøker sammenhengen mellom religiøsitet og depresjon. Nelson (1977) undersøkte ILTB ("indirect lifethreatening behavior") hos 58 pasienter på et hjem for eldre i California. Eksempler på ILTB er handlinger som at pasienten saboterer medisinsk behandling eller med vilje eksponerer seg selv for helsenedbrytende stimuli eller for fare. Nelson fant at desto sterkere pasienten var i sin religiøse tro, jo mindre sannsynlig var det at pasienten utførte ILTB. Forfatteren observerer at "... for the patient who has little to live for and even less to look forward to, religious beliefs offer what may be the only means of transcending the existential limitations of life" (s. 73). Pressman et. al. (1990) studerte 30 eldre kvinner som hadde gjennomgått hoftekirurgi. 
De fant at religiøs tro var forbundet både med lavere nivå av depresjon og bedre gangfunksjon ved utskrivelsen fra sykehuset. De fant også at denne forskjellen ikke kunne forklares med at sykdommens alvorlighetsgrad var forskjellig, men at personer med sterk religiøs tro var mindre tilbøyelige til å være deprimert og mer tilbøyelige til å kunne gå lengre distanser ved utskrivelsen uavhengig av sykdommens alvorlighetsgrad. Koenig et. al.

(1992) undersøkte forekomsten av depresjon hos menn hospitalisert på grunn av somatisk sykdom. En av fem pasienter rapporterte at et religiøst tankeinnhold og/eller religiøse aktiviteter var deres viktigste strategi for å mestre sykdommen. Religiøse mestringsstrategier viste en omvendt korrelasjon med depressive symptomer, også når andre helserelaterte og sosiodemografiske faktorer var kontrollert for. Når 202 av disse pasientene ble reevaluert i forbindelse med en senere innleggelse (gjennomsnittlig 6 måneder etter indeksinnleggelsen) var religiøse mestringsstrategier den eneste faktoren som predikerte lavere depresjonsskårer ved oppfølgingstidspunktet. Smith et. al. (2003) undersøkte i en omfattende og metodologisk sofistikert metastudie hvordan religiøsitet påvirker depresjon når en også tar hensyn til negative ("stressful") livsbegivenheter. De forsøkte også å evaluere to forskjellige modeller for religionens eventuelt modererende effekt på virkningen av negative livsbegivenheter (direkteeffekt versus stressdempende effekt). De konkluderer slik: "Høyere stressbelastning var forbundet med en sterkere invers korrelasjon mellom religiøsitet og depressive symptomer. Resultatene indikerer at den inverse korrelasjonen mellom religiøsitet og depressive symptomer er sterkest når man opplever belastende livshendelser, noe som er i overenstemmelse med hypotesen om religionens rolle som en stressdempende "buffer" som mildner et høyt nivå av stress. Imidlertid var den inverse korrelasjonen mellom religiøsitet og depressive symptomer signifikant på alle nivåer av stressbelastning, noe som også er konsistent med at religionen har en direkte effekt på stress på tvers av stressnivåer. Våre resultater gir derfor støtte til begge modeller om sammenhengen mellom religiøsitet og depressive symptomer" (s. 625. Min oversettelse). (For undersøkelser av religionens betydning for andre aspekter ved psykisk helse og velvære, se for eksempel Bergin, 1983; Cobb, 1956; Koenig et. al., 2012; Park \& Cohen, 1993; Paragment et. al., 2003; Petersen \& Roy, 1985; Witter et. al., 1985).

Hvor ofte er sammenhengen mellom religiøsitet og psykisk helse henholdsvis positiv, negativ eller nøytral? Dernest, omtrent hvor mye av variansen i helse kan forklares av religiøsitet? I en omfattende metaanalyse av 24 empiriske studier av sammenhengen mellom religiøsitet og ulike mål på psykisk helse eller patologi, fant Bergin (1983) følgende: "Av de 30 effekter i vårt oppsett, var det kun 7, eller $23 \%$, som viste et negativt forhold mellom religion og psykisk helse ... Førtisyv prosent indikerte en positiv sammenheng og $30 \%$ ingen sammenheng. $77 \%$ av resultatene står derved i motsetning til hypotesen om religionens negative innvirkning." (s. 176. Min oversettelse). Bergin (1983) fremmer også en metodologisk forklaring på at korrelasjonen mellom religiøsitet og psykisk helse på gruppenivå blir funnet å være konsistent, men relativt svak. En mulig årsak til dette kan ifølge Bergin være at negative og positive effekter av religion på psykisk helse kan utjevne hverandre slik at gjennomsnittseffekten i aggregerte data blir lav. I en annen metastudie om forholdet mellom religion og trivsel/velvære ("well-being") fant Witter et. al. (1985) følgende: "... religion var signifikant og positivt relatert til opplevet velvære. Forholdet mellom religion og opplevet velvære er sterkere for religiøs aktivitet enn for andre mål på religiøsitet. Forholdet er sterkere for utvalg av eldre enn for yngre voksne. Religionen forklarer mellom to og seks prosent av variansen av voksne personers opplevde velvære." (s. 332. Min oversettelse). I sin metastudie om forholdet mellom religion og psykisk helse konkluderer Larson et. al. (1992) med at det er en systematisk forskjell på studiene, idet flesteparten av studiene som har vært utført med ikke-kliniske populasjoner, som for eksempel amerikanske collegestudenter, og hvor en benyttet mål på psykopatologi som ikke var basert på psykiatrisk nomenklatur, enten fant at religion ikke hadde noen effekt eller en negativ effekt oftere enn en positiv effekt. Dette står i motsetning til studier utført på kliniske populasjoner, som for eksempel hospitaliserte psykiatriske pasienter, hvor en benyttet mål på psykopatologi som var basert på psykiatrisk nomenklatur. Der fant man at religiøst engasjement oftere hadde en gunstig effekt enn en negativ effekt. Dette er en meget interessant observasjon som minner om Agerbos (2007) undersøkelse som indikerte at risikofaktorene for selvmord kan være forskjellige for hospitaliserte pasienter enn de er for populasjonen generelt. George et. al. (2000) forsøkte å estimere hvor mye av variansen i helse som kan forklares av de tre faktorene vi nevnte tidligere (adferd, sosial støtte, mening). De estimerte vektingen mellom de tre faktorene slik: adferd forklarer ca. $10 \%$ av variansen, sosial støtte mellom 5 og $10 \%$, og den siste, religion som mening ("sense of coherence") forklarer i følge deres estimat mest av variansen, mellom 20 og 30 \%. Disse estimatene gjelder helse generelt, ikke bare psykisk helse, men det er som vi tidligere har vært inne på sannsynlig at sammenhengen er sterkere for psykisk helse enn for fysisk helse.

\section{Religion og suicidalitet}

Religion kan virke beskyttende fordi den tilbyr både mening og håp. Det kan også være snakk om en slags dobbeltvirkning, idet empiriske studier konsekvent har vist at religiøse personer har mer negative holdninger til selvmord enn ikke-religiøse (Hoelter, 1979; Minear \& Brush, 198081; Neeleman et. al., 1997). Dette er jo ikke så overraskende idet de fleste religioner opererer med et tabu mot selvmord i en eller annen form (Koenig et. al., 2012; van Praag, 2009; Retterstøl \&t Ekeberg, 2009). 
Religion kan derfor virke som en beskyttelsesfaktor for selvmord både gjennom det den tilfører positivt (mening, helsefremmende adferd, sosial støtte), men også gjennom tabu mot selvmord og trussel om straff. Når det gjelder forholdet mellom religion og selvmord er dette tema uløselig knyttet til den franske sosiologen Émile Durkheims navn. Han mente i sin studie Selvmordet (1897/

1951) å kunne dokumentere religionens (særlig katolisismens) effekt som beskyttelsesfaktor. Religionen virker ifølge Durkheim beskyttende på selvmord gjennom faktoren sosial integrasjon. Durkheims studie er gjennomført på populasjonsnivå; hans konklusjon er fremkommet ved at han sammenlignet land og regioner med hensyn til sosiologiske og demografiske variabler. Den sosialt integrerende funksjonen ved religion er det avgjørende:

"religion protects ... because it is a society" (s. 170). (Når vi omtaler religionen ved et samlebegrep slik jeg har gjort i denne artikkelen er det klart at dette dekker over betydelige forskjeller mellom religionene. Når det gjelder betydningen av sosialt nettverk vil dette være høyt i for eksempel katolisismen og islam, men det vil være langt lavere i for eksempel hinduismen.
Når det gjelder tabu mot selvmord som var omtalt på forrige side, vil det også være forskjeller. Eksempelvis har katolisismen og islam et sterkt tabu, mens buddismen har et langt lavere eller endog ikke-eksisterende tabu. Det er likevel slik at de fleste religioner både vektlegger de sosiale båndene mellom trosfeller og har et markert tabu mot selvmord. (Se for eksempel Vijayakumar, 2002; Wasserman \& Wasserman, 2009 for forskjeller mellom religionene).

Durkheims forståelse av religionen ble mer avansert og multifasettert i de 18 årene som gikk mellom utgivelsen av Selvmordet og hans senere verk The elementary forms of religious life (1915/ 1965). Her tar han til orde for at religionen også har en mer direkte effekt, for eksempel ved å dele både tid og rom inn i det hellige og det profane, etc. Det sistnevnte verket er dessverre langt mindre kjent i suicidologien. Durkheims Selvmordet har ikke overraskende avfødt en veritabel flodbølge av empiriske studier på populasjonsnivå hvor en har forsøkt å undersøke Durkheims hypoteser og funn. I de siste 40 årene har særlig Steven Stack utført tallrike studier av denne type.
En hovedkonklusjon i hans og andres studier er at religiøsitet har en invers korrelasjon med selvmordsraten på populasjonsnivå (se for eksempel Bankston, 1983; Neeleman et. al., 1997; Pescosolido, 1990; Stark et. al., 1983; Stack, 1980; $1981 ; 1983 ;$ 1985), men at kausalsammenhenger er vanskelig å bevise på grunn av tallrike confoundere. For eksempel vil viktige faktorer som skilsmissehyppighet og industrialisering i sin tur også korrelere med religiøsitet (Stack, 1980).

\section{Utelatelsen av religiøsitet i suicidalitetsskalaer og $\mathrm{i}$ vurdering av selvmordsfare}

Ut fra det som er nevnt om sammenhengen mellom religiøsitet og helse generelt, og om sammenhengen mellom religiøsitet og selvmord spesielt, skulle en forvente at religiøse tema ville være en selvsagt del av skalaer konstruert for å måle selvmordsrisiko, og på samme måte være en del av vurdering av selvmordsfare. Kehoe \&t Gutheil (1994) fastslår imidlertid etter å ha undersøkt de vanligste skalaene at religiøsitet nærmest er fraværende.

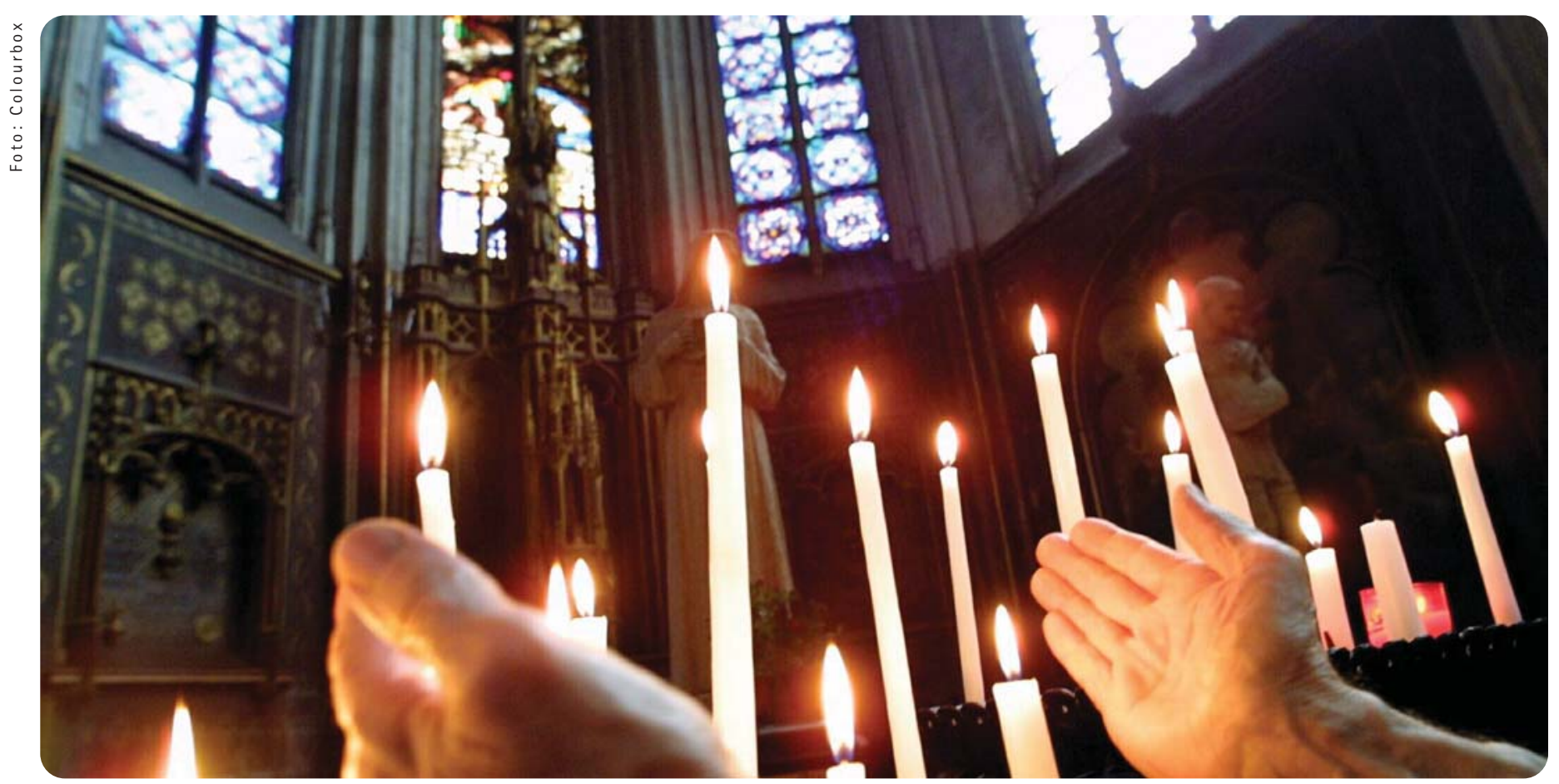


Vi er da i den paradoksale situasjon at samfunnsvitenskapelig og medisinsk forskning finner at religiøsitet er av stor betydning for selvmord og suicidrelaterte tema (depresjon, alienasjon, psykisk helse), men at en ikke tar hensyn til dette i praksis (Gorsuch, 1998; Kehoe \&t Gutheil, 1994). Det er dobbelt oppsiktsvekkende at en i en tidsånd som vektlegger det evidensbaserte ikke tar hensyn til evidensen! Hvilke grunner kan det være til dette? På et overliggende plan er vitenskap og religion rivaliserende meningssystemer (Campbell, 1975; Koestler, 1964; Neeleman \& Persaud, 1995; van Praag, 2009). Dette kan i sin tur ha medført et irrasjonelt fiendskap til religionen som ikke er rettferdiggjort ut fra de vitenskapelige data. Donald Campbell konkluderer slik i sin tale som president [presidental address] i American Psychological Association i 1975: "present day psychology and psychiatry in all their major forms are more hostile to ... traditional religious moralizing than is scientifically justified." (s.1103). Det er liten tvil om at psykologi og psykiatri ignorerer religion både $\mathrm{i}$ teori og praksis (Lukoff et. al., 1995; Neeleman \& Persaud, 1995; Tarakeswar et. al., 2003; Waldfogel \& Wolpe, 1993). I psykologien gjelder fiendtligheten mot religionen både psykodynamiske, adferdsteoretiske og kognitive tilnærminger.

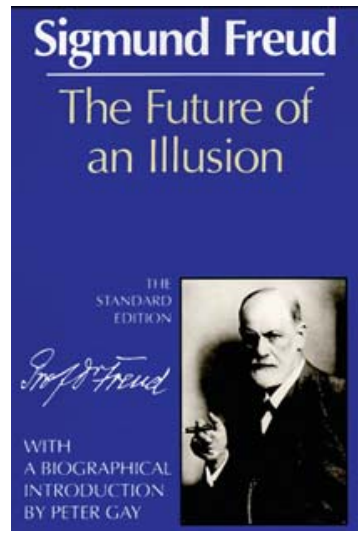

I The future of an illusion (1927) patologiserer Freud religionen ved å se den som en slags universell tvangsnevrose, Skinner (1953) ser religionen som irrasjonelt oppspinn og primært som et middel til sosial kontroll, og Ellis (1980) følger opp med en svært eksplisitt patologisering: "Religion ... is in many respects equivalent to irrational thinking and emotional disturbance." (s. 637).

La oss se på noen konkrete eksempler på hvordan psykologi og psykiatri overser religionen. Larson et. al. (1986) undersøkte hvorvidt forskning utført med kvantitative metoder i fire toneangivende psykiatriske fagtidsskrifter i perioden 1978-1983 inkluderte religion som variabel i en eller annen form. Av de til sammen 2348 undersøkte artiklene, inkluderte kun 59 en operasjonelt definert religiøs variabel ("quantified religious variable"). Forfatterne konkluderer: "... resultatene av vår systematiske analyse indikerer at kvanititativ psykiatrisk forskning som innbefatter religiøsitet har både en absolutt og en relativ lav forekomst sammenlignet med annen adferdsforskning, bruker metodologisk inadekvate mål på religion, og mangler hensiktsmessig anvendelse av nyere begrepsmessige tilnærminger i religionsforskningen... I tillegg vet psykiatrien lite om den gunstige effekten av religion, siden psykiatrisk forskning sjelden inkluderer religion, hverken som uavhengig variabel i forbindelse med psykisk helse eller som avhengig variabel relatert til psykoterapeutiske eller psykososiale intervensjoner." (s. 332/333. Min oversettelse). Sanasone et. al. (1990) undersøkte hvorvidt religiøs tematikk var representert teoretisk og klinisk i opplæringsprogrammer i psykiatri ved amerikanske universiteter, og fant at religion og religiøs tematikk var lite representert. Larson et. al. (1993) undersøkte bruken av religiøse eksempler $\mathrm{i}$ "Glossary of technical terms" i DSM.III-R (Appendix C). Religion var ofte nevnt, men religiøsitet var påfallende ofte benyttet til å illustrere psykopatologi i kasuseksempler. Ifølge forfatterne er denne bruken et eksempel på "cultural insentitivity - the stereotyping of religion as clinically harmful." (s. 1885). I Norge fant Reme et. al. (2009) i en undersøkelse blant studenter at hele $93 \%(\mathrm{~N}=564$, svarprosent 50$)$ svarte at "de ikke opplevde et fokus på menneskers religiøse tro i psykologiutdanningen" (s. 839), samt at "en tredjedel av student- ene mente at psykologifaget er stereotypt og respektløst overfor religiøse mennesker" (s. 841). Denne artikkelen ble etterfulgt av en debatt i Tidsskrift for Norsk Psykologforening om psykologiens manglende hensyntagen til religion (Hagenberg, 2009; Liverød, 2011; Søreide, 2011a; 2011b; Tømmerås, 2009).

En annen mulig årsak til at psykologi og psykiatri overser religionen er at psykoterapeuter generelt er langt mindre religiøse enn befolkningen generelt (Bergin $\& t$ Jensen, 1990; Henry et. al., 1971; Rubenstein, 1994), selv om profesjonelle kan "ta igjen" noe av denne forskjellen med et engasjement i ikke-organisert religion (Bergin \&t Jensen, 1990). Som Beit-Hallahm (1974a) nevner, ble dette misforholdet demonstrert av den amerikanske pioneren i religionspsykologi J.H. Leuba allerede i 1921 (Leuba, 1921). Larson et. als (1988) konklusjon er representativ: "I løpet av 50 år med Gallupundersøkelser har den gjennomsnittlige prosentandelen av amerikanere som rapporterer at de tror på Gud vært 96 prosent... Prosentandelen av profesjonelle i psykisk helsevern som rapporterer at de tror på Gud varierer mellom 43 og 61 prosent ... en betydelig forskjell." (s. 1065. Min oversettelse). I sin store undersøkelse av psykoterapeuter i USA fant Henry et. al. (1971) at mange psykoterapeuter hadde gjennomgått det forfatterne kalte "religious apostasy"; det vil si at de var oppvokst i et religiøst hjem, men senere hadde blitt "omvendt" til agnostisisme, ateisme eller til at de ikke hadde noen spesiell tro. Av de 3000 profesjonelle i Henry et al (1971) sin undersøkelse hadde 900 gjennomgått en slik utvikling. Dette tyder på at mange psykoterapeuter ikke er "nøytrale" i sitt forhold til religion, men har en personlig erfaring i aktivt å ha forlatt religionen, som lett kan medføre et emosjonelt engasjement, med i beste fall en anstrengt ambivalens og i verste fall et aktivt fiendskap som resultat. Rubenstein (1994) finner $i$ en lignende undersøkelse som inkluderte israelske psykoterapeuter at en "religious apostasy" hadde vært til stede forut for beslutningen om å bli psykoterapeut. 


\section{Konklusjon. Viktigheten av å inkorporere religion i selv- mordsrisikovurderinger}

Selv om vitenskapen liker å se seg selv som nærmest upåvirket av sin sosiale og verdimessige kontekst er dette ikke tilfelle, selv ikke for naturvitenskapene (Latour Et Woolgar, 1979; Kuhn, 1970). Denne forbindelsen er enda mer tydelig i praksis, for eksempel vil psykoterapi uvegerlig inneholde moralske verdier, noe som ofte underkommuniseres eller benektes (se for eksempel Beit-Hallahmi, 1974b; Bergin, 1980; Giglio, 1993; Kelly, 1990; Meehl, 1959; Schultz-Ross \&t Gutheil, 1997). I psykoterapien kan situasjonen være slik McClure \&t Tyler (1966) beskriver den i forhold til vitenskapen generelt: "... many scientists abhor value judgements as they abhor witchcraft - all the while tacitly employing those values that have temporarily become standard in their field." (s. 85). Det kan virke som om psykologien og psykiatrien har en slags "blindsone" i forhold til religion, både teoretisk og klinisk. Slik sett kan King (1986) ha noe rett når han hevder at "religion is psychiatry's last taboo". Denne manglende hensyntagen til religion har fått mange til å ta til orde for en økt inkorporering av religiøs tematikk i psykoterapi (Conrad, 1985; Cox, 1994; Thompson, 1971; van Praag, 2009; Waldfogel \& Wolpe, 1993), så vel som i suicidologi (Retterstøl \&t Ekeberg, 2009). Det foreligger en avstand mellom befolkningens religiøsitet og den sekulariserte humanismen som karakteriserer psykoterapeuter. Et i økende grad multireligiøst samfunn, blant annet som følge av innvandring, vil ytterligere aksentuere dette (Cox, 1994). Det har imidlertid vært en klart økende interesse for religion i psykologien og psykiatrien (Belzen, 2005; Hayes \&t Cowie, 2005; Lukoff et. al. 1995; Mills, 2002). For eksempel fant Mills (2002) et empirisk uttrykk for denne økningen ved å studere antall publikasjoner årlig i Medline når han brukte søkeordene 'religion' og 'spiritual/ spirituality'. For eksempel fant det sted en femdobling av antallet slike publika-

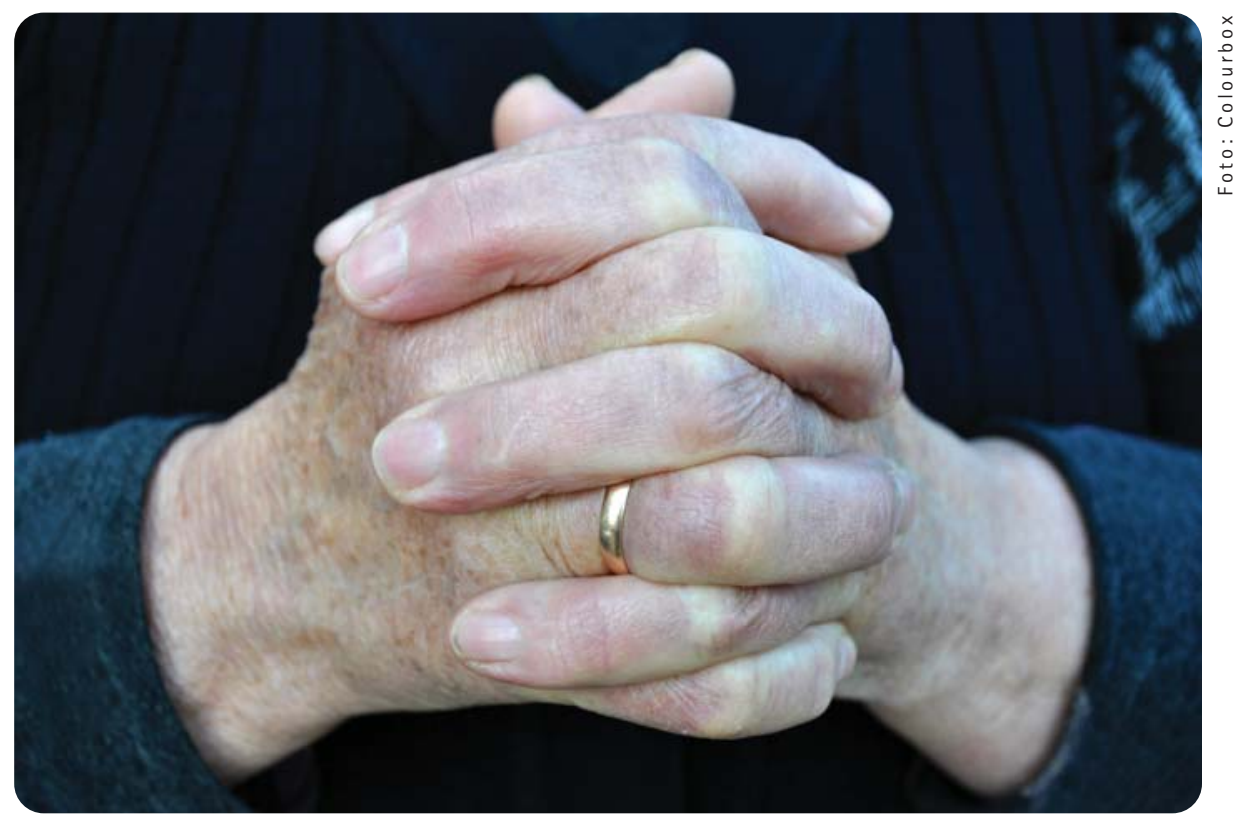

sjoner i perioden 1994-2001 (se kurve over publikasjoner i hele perioden, 19752001, side 1). Denne økte interessen kan delvis skyldes at man er blitt mer oppmerksom på fenomenet kulturell insensitivitet. I USA utarbeidet American Psychiatric Association i 1990 "Guidelines regarding possible conflict between psychiatrist's religious commitments and psychiatric practice" (American Psychiatric Association, 1990). Man fikk også en ny kategori i DSM-IV (American Psychiatric Association, 1994): "religious or spiritual problem" (s. 685). John McIntyre, tidligere president i American Psychiatric Association og Harold Pincus, direktør for forskningsavdelingen samme sted, konkluderer med at dette tillegget i DSM-IV er et tegn på "the profession's growing sensitivity not only to religion, but to cultural diversity generally". (1994. Referert i Lukoff et. al., 1995. s. 481). Her i landet har Norsk Psykologforening vært med på å utgi heftet Kultur, kontekst og psykopatologi (Baarnhielm et. al. 2010), som ble sendt ut til samtlige medlemmer, og som har som hensikt å øke bevissheten om kulturell sensitivitet. I 2012 utkom det to norske bøker om religion, spiritualitet og helse; Åndelighet - mening og tro. Utfordringer i profesjonell praksis (Danbolt \& Nordhelle, 2012) og Det hellige som kilde til helse (Meland, 2012).
Fagtidsskriftet Impuls. Tidsskrift for Psykologi har planlagt et temanummer om religion i 2013. På Sykehuset Østfold har man inkorporert religion i selvmordsrisikovurderingene. Rutinen Observasjon og kartlegging av selvmordsrisiko. Vurdering av selvmordsrisiko (Sykehuset Østfold, 2011) beskriver hvilke faktorer det er nødvendig å kartlegge i vurdering av selvmordsrisiko. Faktorene er inndelt i

1) Statistiske risikofaktorer,

2) Endringsfølsomme risikofaktorer, og

3) Beskyttelsesfaktorer.

Den sistnevnte kategorien inneholder følgende:

1. Nettverk/relasjoner/Annet.

2. Håp/fremtidsperspektiv/meningsgivende aktiviteter/"reasons for living". 3. Religion, livssyn, holdningsmessige sperrer mot selvmord.

I lys av det som er funnet i empirisk forskning om religion og helse generelt og religion og selvmord spesielt, er det påfallende at pasientens religion, livssyn og verdier ikke i større grad tas med i vurderinger av selvmordsrisiko. Ut fra at både psykologi og psykiatri har en selvforståelse som empirisk baserte vitenskaper, er det vanskelig å forstå at de ikke tar mer hensyn til empirien. 
En økt integrasjon av religiøse temaer i vurderinger av selvmordsrisiko er påkrevet. Suicidologien har i likhet med psykologien og psykiatrien vært enøyde i sitt perspektiv. Dette kan lett resultere i ukomplette og ufullstendige vurderinger av selvmordsrisiko. Det er lett å slutte seg til O'Briens (1982) konklusjon: "Without attention to the dimension of an individual's spiritual or religious orientation, attitudes, and behavior, the construct of patient as bio-psycho-social-spiritual being is incomplete." (s. 79).

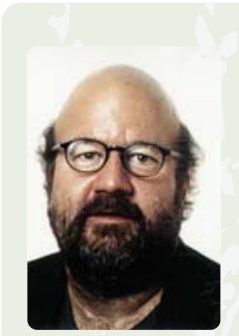

Kim Larsen er psykologspesialist ved Sykehuset Østfold og RVTS/Ø og jobber også ved NSSF. Han er spesialist i klinisk samfunnspsykologi og arbeids- og organisasjonspsykologi. Faglige spesialinteresser er: sosialpsykologi, Freudbiografi og psykoanalysens historie, psykiatrihistorie og suicidologi.

\section{Referanser:}

Agerbo, E. (2007). High income, employment, postgraduate education, and marriage. A suicidal cocktail among psychiatric patients. Archives of General Psychiatry, 64, 1377-1384.

American Psychiatric Association. (1990). Guidelines regarding possible conflict between psychiatrist's religious commitments and psychiatric practice. American Journal of Psychiatry, 147, 542. American Psychaitric Association. (1994). Diagnostic and statistical manual of the mental disorders. 4th. Edition. Washington D.C.: American Psychaitric Association.

Antonovsky, A. (1979). Health, stress and coping. San Fransisco: Jossey-Bass.

Aries, P. (1983). The hour of our death. Harmondsworth: Penguin.

Baarnhielm, S. et. al. (2010). Kultur, kontekst og psykopatologi. Manual for diagnostisk intervju basert på kulturformuleringen i DSM-IV. Oslo: Nakmi.

Bankston, W.B. et. al. (1983). Religion and suicide: A research note on sociology's "one law". Social Forces, 63, 521- 528.

Becker, E. (1973). The denial of death. New York: Free Press.

Beit-Hallahmi, B. (1974a). Salvation and its vicissitudes. Clinical psychology and political values. American Psychologist, 124-129.

Beit-Hallahmi, B. (1974b). Psychology of religion 1880-1930. The rise and fall of a psychological movement. Journal of the History of the Behavioral Sciences, 10, 84-90.
Belzen, J.A. (2005). In defence of the object: On trends and directions in the psychology of religion. International Journal for the Psychology of Religion, 15, 1-16.

Berger, P.L. (1967). The sacred canopy. Elements of a sociological theory of religion. New York: Doubleday.

Berger. P.L. (1980). The heretical imperative. Contemporary possibilities of religious affirmation. New York: Anchor Books.

Berger, P.L. \&t Kellner, H. (1982). Sociology reinterpreted. An essay on method and vocation. Harmondsworth: Penguin.

Berger, P.L. et. al. (1974). The homeless mind. Modernization and consciousness. Harmondsworth: Penguin.

Bergin, A.E. (1980). Psychotherapy and religious values. Journal of Consulting and Clinical Psychology, 48, 95-105.

Bergin, A.E. (1983). Religiosity and mental health: A critical reevaluation and meta-analysis. Professional Psychology: Research and Practice, 14, 170-184. Bergin, A.E. \&t Jensen, J. (1990). Religiousity of psychotherapists: A national survey. Psychotherapy, 27, 3-7.

Campbell, D.T. (1975). On the conflicts between biological and social evolution and between psychology and moral tradition. American Psychologist, 30, 1103-1126.

Cobb, B. (1956). Psychological impact of long illness and death of a child on the family circle. Journal of Pediatrics, 49, 746-751.

Cohen, R.E. \&t Syme, S.L. (Red). (1985). Social support and health. Orlando: Academic Books.

Conrad, N.L. (1985). Spiritual support for the dying. Nursing Clinical of North America, 20, 415-426.

Cox, J.L. (1994). Psychiatry and religion. A general psychiatrist's perspective. Psychiatric Buleltin, 18, 673-676.

Danbolt, T.F. \&t Nordhelle, G. (2012). Åndelighet Mening og tro. Utfordringer i profesjonell praksis. Oslo: Gyldendal.

Durkheim, E. (1897/1951) Suicide. A study in sociology. Glencoe: Free Press. Norsk forkortet utgave: Selvmordet. En sosiologisk undersøkelse. Oslo: Gyldendal. 1978.

Durkheim, E. (1915/1965). The elementary forms of religious life. New York: Free Press.

Ellis, A. (1980). Psychotherapy and atheistic values. A response to A.E. Bergin's 'Psychotherapy and religious values'. Journal of Consulting and Clinical Psychology, 40, 635-639.

Frankl, V.E. (1959/1984). Man's search for meaning. Revised and updated. New York: Simon \&t Schluster.

Freud, S. (1927). The future of an illusion. I The standard edition of the complete psychological works of Sigmund Freud. London: Hogarth Press. 1974. Vol. 21. Ss. 1-56.

Geertz, C. (1966). Religion as a cultural system. I M. Banton (Red.): Antropological approaches to the study of religion. London: Tavistock.
George, L.K. et al. (2000). Spirituality and health: What we know, and what we need to know. Journal of Social and Clinical Psychology, 19, 102-116.

Giglio, J. (1993). The impact of patient's and therapist's religious values on psychotherapy. Hospital and Community Psychiatry, 44, 768-771. Gorsuch, R.L. (1998). Psychology of religion. Annual Review of Psychology, 39, 201-221.

Hagenberg, H. (2009). Religion i psykologiutdannelsen. Tidsskrift for Norsk Psykologforening, 46, 1100.

Hayes, M.A. \&t Cowie, H. (2005). Psychology and religion: mapping the relationship. Mental Health, Religion \& Culture, 8, 27-33.

Henry, W.E. et. al. (1971). The fifth profession. Becoming a psychotherapist. San Fransisco: JosseyBass.

Hoelter, J.W. (1979). Religiousity, fear of death and suicide acceptability. Suicide and LifeThreatening Behavior, 9, 163-172.

Idler, E.L. \&t Kasl, S.V. (1992). Religion, disability, depression, and the timing of death. American Journal of Sociology, 97, 1052-1079.

Jarvis, G.K. \&t Northcott, H.C. (1987). Religion and differences in morbidity and morality. Social Science and Medicine, 25, 813-824.

Kehoe, N.C. \& Gutheil, T.G. (1994). Neglect of religious issues in scale-based assessment of suicidal patients. Hospital and Community Psychiatry, 45, 366-369.

Kelly, T.A. (1990). The role of values in psychotherapy: A critical review of process and outcome effects. Clinical Psychoogy Review, 10, 171-186.

King, H. (1986). Religion. The last taboo. Washington D.C.: APA Press.

Koenig, H.G. et al. (1992). Religious coping and depression among elderly, hospitalized medically ill men. American Journal of Psychiatry, 149, 1693-1700.

Koenig, H.G. et al. (1997). Modeling the crosssectional relationship between religion, physical health, social support, and depressive symptoms. Journal of Geriatric Psychiatry, 5, 131-144.

Koenig, H.G. et al. (1998). Religiousity and remission of depression in medically ill older men. American Journal of Psychiatry, 155, 536-542.

Koenig, H.G. et al. (2012). A history of religion, medicine, and health care. I H.G. Koenig et. al. (Red.). Handbook of religion and health. Second edition. Oxford: Oxford University Press. Kap. 1. Ss. 15-34.

Koenig, H.G. et al. (2012). Suicide. I H.G. Koenig et. al. (Red.): Handbook of religion and health. Second edition. Oxford: Oxford University Press. Kap. 8. Ss. 175-190.

Koenig, H.G. et al. (2012). Handbook of religion and health. Oxford: Oxford University Press.

Koestler, A. (1964). The sleepwalkers. A history of Man's changing vision of the universe. London: Penguin. 
Kuhn, T.S. (1962/1970). The structure of scientific revolutions. Second edition, enlarged. London: University of Chicago Press.

Larson, D.B. et al. (1986). Systematic analysis of research on religious variables in four major psychiatric journals, 1978-1982. American Journal of Psychiatry, 143, 329-334.

Larson, D.B. et al. (1988). The couch and the cloth: The need for linkage. Hospital and Community Psychiatry, 39, 1064-1069.

Larson, D.B. et al. (1992). Association between dimensions of religious commitment and menta health reported in the American Journal of Psychiatry and Archives of General Psychiatry: 1978-1989. American Journal of Psychiatry, 149 557-559.

Larson, D.B. et al. (1993). Religious content in the DSM-III-R glossary of technical terms. American Journal of Psychiatry, 150, 1884-1885

Larson, D.B. et al. (1997). Scientific research on spirituality and health: A consensus report. Rockville: National Institute for Mental Health Research.

Latour, B. \& Woolgar, S. Laboratory life. The construction of scientific facts. Chichester: Princeton University Press.

Levin. J.S. (1994). Religion and health: Is there an association, is it valid, and is it causal? Social Science and Medicine, 38, 1475-1482.

Leuba, J.H. (1921). The belief in God and immortality. Chicago: Open Court.

Liverød, S.R. (2011). Religionens frykt og tankefeller. Tidsskrift for Norsk Psykologforening, 48, 798-799.

Lukoff, D. et al. (1995). Cultural considerations in the assessment and treatment of religious and spiritual problems. Psychiatric Clinics of North America, 18, 467-485.

May, R. (1950/1977). The meaning of anxiety. Revised edition. New York: W.W. Norton.

Mills, P.J. (2002). Spirituality, religiousness, and health: From research to clinical practice. Annals of Behavorial Medicine, 24, 1-2.

McClure, G.T. \& Tyler, F.B. (1966). Policy decisions in science: Psychological considerations and implications for psychology. Journal of general Psychology, 77, 69-86.

Meehl, P.E. (1959). Religious factors and values in counselling: A symposium. Some technical and axiological problems in the therapeutic handling of religious and valuational material. Journal of Counseling Psychology, 6, 255-259.

Meland, E. (2012). Det hellige som kilde til helse Stavanger: Eide forlag.

Minear, J.D. \& Brush, L.R. (1980-81). The correlations of attitudes toward suicide with death anxiety, religiousity, and personal closeness to suicide. Omega, 11, 317-324.

Neeleman, J. \& Persaud, R. (1995). Why do psychiatrists neglect religion? British Journal of Medical Psychology, 68, 169-178.

Neeleman, J. et. al. (1997). Tolerance of suicide, religion and suicide rates: an ecological and individual study in 19 Western countries. Psychological Medicine, 27, 1165-1171.
Nelson, F.L. (1977). Religiousity and self-destructive crises in the institutionalized elderly. Suicide and Life-Threatening Behavior, 7, 67-74.

Norcross. J.C. \&t Wogan, M. (1987). Values in psychotheary: A survey of practioner's beliefs. Professional Psychology: Research and Practice, 18, 5-7.

0'Brien, M.E. (1982). Religious faith and adjustment to long-term hemodialysis. Journal of Religion and Health, 27, 68-80.

Pargament, K.I. (1990). God help me: Toward a theoretical framework of coping for the psychology of religion. Journal for the Scientific Study of Religion, 2, 195-224.

Pargament, K.I. (1992). Of means and ends: Religion and the search for significance. International Journal for the Psychology of Religion, 4, 201-229. Pargament, K.I. et al. (2003). Red flags and religious coping: Identifying some religious warning signs among people in crisis. Journal of Clinical Psychology, 59, 1335-1348.

Park, C.L. \& Cohen, L.H. (1993). Religious and nonreligious coping and the death of a friend. Cognitive Therapy and Research, 17, 561-577.

Pescosolido, B.A. (1990). The social context of religious integration and suicide: Pursuing the network explanation. Sociological Quarterly, 31 337-357.

Petersen, L.R. \&t Roy, A. (1985). Religiousity, anxiety, and meaning and purpose: Religion's consequences for psychological well-being. Review of religious Research, 27, 49-62.

Pilisuk, M. \& Parks, S.H. (1986). The healing web: Social networks and human survival. Hanover: University Press of New England.

Pressman, P. et. al. (1990). Religious belief, depression, and ambulaton status in elderly women with broken hips. American Journal of Psychiatry, 147 758-760.

Reme, S.E. et. al. (2009). Er religion neglisert i psykologiutdanningen? Tidsskrift for Norsk Psykologforening, 46, 837-842.

Retterstøl, N. \& Ekeberg, Ø. (2009). Christianity and suicide. I D. Wasserman \& C. Wasserman (Red.): Oxford textbook of suicidology and suicide prevention. A global perspective. Kap. 9. Ss. 57-62.

Rubenstein, G. (1994). Political attitudes and religiousity levels of Israeli psychotherapy practioners and students. American Journal of Psychotherapy, 3, 441-454.

Sanasone, R.A. et. al. (1990). The role of religion in psychiatric education. A national survey. Academic Psychiatry, 14, 34-38.

Schultz-Ross, R.A. \&t Gutheil, T.G. (1997). Difficulty in integrating spirituality into psychotherapy. Journal of Psychotherapy: Practice and Research $6,130-138$.

Skinner, B.F. (1953). Science and human behaviour. London. Free Press.

Smith, T.B. et. al. (2003). Religiousness and depression: Evidence for a main effect and the moderating influence of stressful life events. Psychological Bulletin, 129, 614-638.
Spilka, B. et. al. (1985). A general attribution theory for the psychology of religion. Journal for the Scientific Study of Religion, 24, 1-20.

Stack, S. (1980). Religion and suicide: A reanalysis. Social Psychiatry, 15, 65-70.

Stack, S. (1981). Suicide and religion: A comparative analysis. Sociological Focus, 14, 207-220

Stack, S. (1983). The effect of the decline in institutionalized religion on sucide, 1954-1978. Journal for the Scientific Study of Religion, 22, 239252.

Stack, S. (1985). The effect of domestic/religious individualism on suicide, 1954-1978. Journal of Marriage and the Family, 51, 229-247.

Stark, R. et. al. (1983). Beyond Durkheim: Religion and suicide. Journal for the Scientific Study of Religion, 22, 120-131.

Szasz, T.S. (1970). The manufacture of madness. A comparative study of the Inquisition and the Mental health movement. London: Paladin Books.

Sykehuset Østfold. (2011). Observasjon og kartlegging av selvmordsrisiko. Vurdering av selvmordsrissiko. Elektronisk kvalitetshåndbok. Prosedyresamling. Dokumentnummer KPO/17-05. Søreide, L. (2011a). Eksistensielt vakuum i Harald Schelderups hus. Tidsskrift for Norsk Psykologforening, 48, 690-692.

Søreide, L. (2011b). Et svar og et ubesvart spørsmål. Tidsskrift for Norsk Psykologforening, 48, 1118-1119. Tarakeshwar, N. et. al. (2003). Religion. An overlooked dimension in cross-cultural psychology. Journal of Cross-Cultural Psychology, 34, 377-394. Templer, D.I. \& Veleber, D.M. (1980). Suicide rate and religion within the United States. Psychological Reports, 47, 898.

Thompson, J.H. (1971). Spiritual considerations in psychotherapy. British Journal of Psychiatry, 119, 71 72.

Tømmerås, S. (2009). Teologi i terapirommet. Tidsskrift for Norsk Psykologforening, 46, 1236.

van Praag, H.M. (2009). The role of religion in suicide prevention. I D. Wasserman \& C. Wasserman (Red.): Oxford textbook of suicidology and suicide prevention. A global perspective. Oxford: Oxford University Press. Kap. 2. Ss. 7-12.

Vijayakumar, L. (2002). Religion - en beskyttende factor ved selvmord. Suicidologi, 7, No. 2, 9-12.

Waldfogel, S. \& Wolpe, P.R. (1993). Using awareness of religious factors to enhance interventions in consultation-liason psychaitry. Hospital and Comminity Psychaitry, 44, 473-477.

Wasserman, D. \& Wasserman, C. (Red.). (2009). Suicide in a religious and cross-cultural perspective. I Oxford textbook of suicidology and suicide prevention. A global perspective. Kapittel 1-12. Ss. 3-84

Weisskopf-Joelson, E. (1980). Values: The enfant terrible of psychotherapy. Psychotherapy: Theory, research and practice, 17, 459-466.

Witter, R.A. et. al. (1985). Religion and subjective well-being in adulthood: A quantitative synthesis. Review of Religious Research, 26, 332-342. 